\title{
Management of Charcoal Rot (Macrophomina phaseolina) Infection in Geranium (Pelargonium graveolens L.) Using Biocontrol Agents and Essential Oils
}

\author{
Azza A. Ghazi ${ }^{1}$, Eman A. Attia ${ }^{2}$ and Nahed M. Rashed ${ }^{3}$ \\ ${ }^{1}$ Microbiology Dept., Soils, Water and Environ. Research Inst., ARC, Egypt. \\ ${ }^{2}$ Ornamental Plants and Landscape Gardening Res. Dept., Hort. Res. Inst., ARC, Egypt. \\ ${ }^{3}$ Vegetable and Ornamental Department, Faculty of Agriculture. Damietta University, \\ Damietta, Egypt
}

\begin{abstract}
$\mathrm{N}$ a trial to control charcoal rot disease (Macrophomina phaseolina) in geranium using ecofriendly strategies, antagonistic microbes and essential oils were used. the treatments included three bacterial isolates, Bacillus polymixa, B. circulance, B. Subtilis and one fungus Tricoderma harzianum in addition to five essential oils, (Syzygium aromaticum(cloves), Ocimum basilicum L. (basil), Mentha spicata (Spearmint), Majorana hortensis Moench (Marjoram) and Mentha piperita L. (Peppermint). The in vitro antagonistic effect of microbial isolates and essential oils against $M$. phaseolina isolated from infected geranium was estimated in Petri plats, The essential oils were used in three concentrations 1, 3 and 5 microliter/plate. the most promising treatments were applied in an artificially infested geranium in a greenhouse experiment along two growing seasons of 2017,2018. The in vitro screening step indicated that among the treatments, Bacillus subtilis and Trichoderma harzianum were the most promising microbes against the fungal pathogen under study using the dual culture technique. On the other hand, Peppermint oil recorded the highest reduction in radial growth of pathogen followed by Basil oil while Marjoram oil had no effect on the growth of pathogen. The green house experiment showed that, most treatments were efficient in pathogenicity reduction but the microbial treatment exhibited an advantage over essential oil where growth and yield parameters were sharply improved. The maximum enhancement was attained at $\mathrm{T}_{5}$ treatment (infested + dipping for $30 \mathrm{~min}$ before planting and spraying with $T$. harzianum after every cutting process) at all cuts during 2017 and 2018 seasons. Also, T. harzianum increased oil \%, which recorded $0.45,0.30$ and $0.38 \%$ at 2017 season and $0.47,0.31$ and $0.39 \%$ at 2018 season for $1^{\text {st }} 2^{\text {nd }}$ and $3^{\text {rd }}$ cut respectively. Therefore, microbial and essential oil treatments not only reduced the fungal infection but also enhanced vegetative growth of geranium plants.
\end{abstract}

Keywords: Geranium; Bacillus; Trichoderma; Essential oils; Charcoal rot.

\section{Introduction}

Rose geranium (Pelargonium graveolens L.) is an aromatic, bedding plant, cultivated mainly for its essential oil production (Eiasu et al. 2012). Geranium essential oil possesses high economic value in international market because of its very profound and strong rose-like fragrance in addition to its medicinal importance like bleeding staunch, wounds healing, ulcers disorders as well as treatment of dysentery, diarrhea and colic (Matthews 1995). Geranium is now substantial aromatherapy oil used as balancing oil for both mind and body (Dormon and Deans 2000). Fungal plant pathogens are the main concern to agricultural production worldwide. The estimated yield decline as a result to plant diseases is about 25 to $50 \%$ in the western and developing countries, respectively (Gohel et al. 2006).

Charcoal rot, caused by the fungus Macrophomina phaseolina (Tassi) is a root and stems pathogen of many plants (Gupta et al. 2012). M. phaseolina is widespread soil-borne pathogen infects a widehost range, great longevity with high competitive saprophytic potency ( $\mathrm{Su}$ et al. 2001). Infection with charcoal rot was stimulated by abiotic factors such as drought stress and light-textured soil and/or biotic factors like stress associated with host reproduction (Mihail 1989). This can be attributed to the overriding of this pathogen in the hot months of the year especially in the late spring/early summer when temperatures often exceed $30^{\circ} \mathrm{C}$ and a many

*Corresponding author e-mail: ghaziazza@yahoo.com 
plants wilt and rapidly die in the field (Fang et al. 2011). Also, M. phaseolina survives in soil and on debris of diseased plants as resilient resistant structures called microsclerotia that allow the fungus to survive for years (Zveibil et al. 2012). The production of too much microsclerotia in the soil make its control is a difficult duty (Naseri 2008)

In addition, successive use of chemical fungicides may lead to the emergence of resistanant strains and causes environmental pollution (Muthomi et al. 2007). On the other hand, biological control and essential oils provide an ecofriendly solution alternative to chemical control. For biological control, several microbes like Bacillus pumilus, B.subtilis and B.licheniformis as well as Trichoderma viride and Pseudomonas species have been considered as a biocontrol agents against pathogens through their ability to serve as a source of bioactive compounds and plant growth promoting such as antibiotic production, colonization site competition, production of hydrogen cyanide, hydrolytic enzymes, siderophores, ammonia, fluorescent pigments and/or antimicrobial volatiles (Keshavarz-Tohid et al. 2017; Sadeghi et al. 2017; Lu et al. 2017; Omara et al. 2018). For essential oils like Pelargonium roseum, Carum carvi, Pimenta dioica, Cymbopogon nardus and Thymus vulgaris have been considered antifungal activity which may be attributed to their major ingredients or a synergistic or antagonistic effect with various compounds. Also, plant extracts are among the biological control agents that directly affect the plant pathogens and can induce resistance in plants against phytopathogens (Mishra and Raja 1999). Recently, plant extracts have gained considerable attention as alternative options to synthetic fungicides and efforts have been made to utilize these extracts in the control strategies against plant diseases (Elsharkawy and El-Sawy 2015; Elkhwaga et al. 2018).

Several studies have demonstrated
that microorganisms and essential oils
can be used as a biocontrol agent in
controlling a number of plant diseases
with a high efficacy i.e. extract of lantana showed
broad antifungal activity against Aspergillus flavus
and A. niger (Fayaz et al. 2017), Colletorichum
falcatum (Sreeramulu et al. 2017). Also, charcoal
rot infection was substantially reduced by
seed coating of mungbean and sunflower by $T$.
harzianum, Gliocladium virens and Streptomyces

Env. Biodiv. Soil Security Vol. 2 (2018) sp. (Hussain et al.1990).

Our study aimed to isolate and identify of charcoal rot (Macrophomina phaseolina), from stem tissues of infected geranium plant and controlling using some of antagonistic microbes and essential oils under invitro and invivo conditions.

\section{Materials and Methods}

Microorganisms used

Three bacterial strains, Bacillus polymixa, $B$. subtlis and $B$. circulance as well as one fungal strain, Trichoderma harzianum were used in the present study which provided from Bacteriology Laboratory, Sakha Agricultural Research Station, Kafr El-Sheikh, Egypt.

Essential oils used

Five types of essential oils, cloves (Syzygium aromaticum), basil (Ocimum basilicum L.), Spearmint (Mentha spicata), Marjoram (Majorana hortensis) and Peppermint (Mentha piperita L.), were supplied from Assiut Organic Company for oils extractions, Egypt.

\section{Charcoal rot isolation}

The fungal pathogen was isolated from stem tissues of infected geranium plant bearing fungal sclerotia and showing charcoal rot symptoms. The sample was washed under tab water to remove soil particles then the stem was fragmented into small segments $(5-10 \mathrm{~mm})$, then sterilized for 2 minutes with $1 \%$ sodium hypochlorite and washed 3 times with sterilized distilled water. The pieces were placed on Chloroneb Mercury Rose Bengal Agar (CMRA) medium and incubated at $28^{\circ} \mathrm{C}$ for 7 days Meyer et al. (1973). A charcoal like dust of Macrophomina phaseolina was taken from the growing edge of fungal growth, spread onto Petri plates containing glucose agar medium $\mathrm{gl}^{-1}$ (glucose, 20 ; agar, 20 ), and incubated at $28^{\circ} \mathrm{C}$ for 7 days. Single colony was then sub cultured on CMRA agar medium and identified according to Barnett and Hunter (1972). The fungal isolate was stored on PDA slants at $4{ }^{\circ} \mathrm{C}$.

\section{Antagonistic activity of bacterial strain and} T.harzianum against M.phaseolina

The effect of bacterial and fungal strains on growth of $M$. phaseolina was proceeded using dual culture technique according to Kucuk and Kivanc (2003). In case of bacterial strains, each bacterial strain was spotted at 4 equidistant points along the perimeter of the plate in three replicates. Plates were incubated at $28^{\circ} \mathrm{C}$ for $48 \mathrm{~h}$ then $5-\mathrm{mm}$ 
disc from the edge of a 7-day-old culture of Macrophomina phaseolina was transferred to the center of PDA plate then incubated for another 5 days at the same conditions Landa et al. (1997). Plates without bacterial inoculation were used as control. While, in case of T. viride, one mycelial disc was placed on opposite poles of PDA plates and incubated at $25^{\circ} \mathrm{C}$. Radial growth of pathogen was measured after 5 days and compared to control. At the end of incubation period, the length of radial growth toward the bacteria $(\mathrm{Ri})$ and that on a control plate $(\mathrm{Rc})$ were recorded. The relative growth inhibition was calculated according to the following formula: (Ri-Rc)/Rc x 100 (Fokkema, 1973).

Antagonistic activity of essential oils against M. phaseolina

The effect of studied essential oils on mycelia growth of M.phaseolina according to Boyraz and Ozcan (2006) with some modifications. Five millimeter mycelia discs from the growing margins of a seven days old culture were placed on the center of PDA plate and then 1,3 and $5 \mu$ of essential oil were added on $5 \mathrm{~mm}$ sterile Watman No. 1 paper disc in center of each petri plate cover. The petri plates were sealed well using parafilm and incubated at $28^{\circ} \mathrm{C}$ for 4 days. Distilled water was used as control instead of oils. The inhibition rate was calculated according to equation developed by Deans and Svoboda (1990): $\mathrm{I}=\mathrm{C}-\mathrm{T} /$ $\mathrm{C} \times 100$, where: $\mathrm{I}=$ Mycelial inhibition percentage, $\mathrm{C}=$ mean of colony diameter of control, $\mathrm{T}=$ mean of colony diameter of treatment.

Plant growth promoting ability of the studied strains

Indole-3-acetic acid (IAA) analysis was done as reported by Ivanova et al. (2001). Siderophore production was determined by the Schwyn and Neilands (1987) method using CAS agar plates. Cyanhydric acid $(\mathrm{HCN})$ production was carried out according to the method described by (Lorck 1948). Chitinase by Saima et al. (2013) and protease by Sjodahl et al. (2002).

\section{Greenhouse experiment}

Pot experiment was carried out at Sakha agricultural research station, Kafrelsheikh, to investigate the effect of dipping and spraying with the two most promising microbes, strains (B. subtilis and T. harzianum), and the two most potent essential oils (peppermint and basil), to control of $M$. phaseolina infested geranium plants along two growing seasons 2017 and 2018. Pot experiment was conducted in loam soil in texture having the following characteristics: $\mathrm{pH}$, 7.90; EC, $0.166 \mathrm{dS} \mathrm{m}^{-1}$; organic matter (\%), 1.32; soluble cations $\mathrm{Ca}^{+2}, \mathrm{Mg}^{+2}, \mathrm{Na}^{+}$and $\mathrm{K}^{+}\left(\right.$meq $\left.\mathrm{L}^{-1}\right)$, $0.76,0.59,0.45$ and 0.17 , respectively; soluble anions $\mathrm{CO}_{3}^{--}, \mathrm{HCO}_{3}, \mathrm{Cl}^{-}$and $\mathrm{SO}_{4}^{--}\left(\mathrm{meq} \mathrm{L} \mathrm{L}^{-1}\right), 0.0$, $1.0,0.56$ and 0.41 , respectively; available $\mathrm{N}(\mathrm{Kg}$ $\left.\mathrm{mg}^{-1}\right), 7.44$; available $\mathrm{P}\left(\mathrm{Kg} \mathrm{mg}^{-1}\right), 6.80$; available $\mathrm{K}\left(\mathrm{Kg} \mathrm{mg}^{-1}\right)$, 331.1. Also, total count of bacteria, $140 \times 10^{7} \mathrm{CFU}$; total count of fungi, $55 \times 10^{4} \mathrm{CFU}$ and total count of actinomycetes, $35 \times 10^{5} \mathrm{CFU}$ (Allen 1959).

\section{Soil infestation}

Seeds of wheat were thoroughly washed, air dried and then distributed into $500 \mathrm{ml}$ bottles then autoclaved at $1.5 \mathrm{~kg} \mathrm{~cm}^{-2}$ for $45 \mathrm{~min}$. bottles were inoculated with discs of 7 days old cultures and incubated at $28 \pm 11^{\circ} \mathrm{C}$. After sufficient growth had been obtained, contents of the bottles of each isolate were thoroughly mixed. Pots of $25 \mathrm{~cm}$ in diameter were filled with $5 \mathrm{Kg}$ autoclaved $(1.5 \mathrm{~kg} /$ $\mathrm{cm}^{2}$ for $45 \mathrm{~min}$ ) soil then mixed thoroughly with the prepared inoculum at the rate of $10 \mathrm{~g} \mathrm{~kg}^{-1}$ and kept moistened 7 days before planted. Geranium cutting were planted on $15^{\text {th }}$ April in the two seasons which supplied from Sakha Horticulture Research Station, Kafrelsheikh, Egypt. The experiment was carried out as 11 x 4 complete randomized block designed, i.e. 11 treatment and 4 replicates for each treatment under soil infestation conditions with $M$. phaseolina (Table 1). Mineral fertilizers program was applied according to the recommendations of Ministry of Agriculture and Land Reclamation.

\section{Measurements}

Three cuts were obtained on $1^{\text {st }}$ October, $1^{\text {st }}$ March and $16^{\text {th }}$ June at the two seasons. Enumeration of dead plants was established at the third cutting. Measurements included plant height (cm plant ${ }^{-1}$ ), number of branch plant ${ }^{-1}$, leaves to stem ratio, herb yield fresh weight $\left(\mathrm{g} \mathrm{plant}^{-1}\right)$, infection percentage and oil percentage.

\section{Statistical analysis}

The statistical analysis was done for data using CoStat software program by LSD method (Steel and Torrie 1980).

\section{$\underline{\text { Results }}$}

\section{Charcoal rot isolation}

According to Kaura et al. (2013), the fungal genus was morphologically identified as $M$. phaseolinaas shown in Table 2. When the epidermis of lower stems and taproots is removed (by scraping with the Thumb nail), Env. Biodiv. Soil Security Vol. 2 (2018) 
TABLE 1. Treatments used for greenhouse experiment.

\begin{tabular}{|c|c|}
\hline Symbol & Treatment \\
\hline$T_{1}$ & Uninfested and untreated (control) \\
\hline $\mathbf{T}_{2}$ & Infested and untreated \\
\hline $\mathbf{T}_{3}$ & Infested and treated with commercial fungicide (Vitavax $20040 \%$ ) \\
\hline $\mathbf{T}_{4}$ & $\begin{array}{l}\text { Infested soil }+ \text { cuts dipped }(30 \mathrm{~min}) \text { beforeplanting in ten diluted broth culture* of } B \text {. subtilis and sprayed } \\
\text { with }\left(5 \mathrm{ml} \mathrm{pot}^{-1}\right) \text { after every cutting with the same microbial dilution }\end{array}$ \\
\hline $\mathbf{T}_{5}$ & $\begin{array}{l}\text { Infested soil }+ \text { cuts dipped }(30 \mathrm{~min}) \text { before planting in ten diluted broth culture* of } T \text {. harzianum and } \\
\text { sprayed with }\left(5 \mathrm{ml} \mathrm{pot}^{-1}\right) \text { after every cutting with the same microbial dilution }\end{array}$ \\
\hline$T_{6}$ & $\begin{array}{l}\text { Infested soil }+ \text { cuts dipped }(10 \mathrm{~min}) \text { before plantingin peppermint oil }(300 \mathrm{ppm}) \text { and sprayed }\left(5 \mathrm{ml}^{-1} \mathrm{pot}^{-1}\right) \\
\text { after every cutting with same oil dilution }\end{array}$ \\
\hline $\mathbf{T}_{7}$ & $\begin{array}{l}\text { Infested soil }+ \text { cuts dipped }(10 \mathrm{~min}) \text { before planting in peppermint oil }(500 \mathrm{ppm}) \text { and sprayed }\left(5 \mathrm{ml}^{\mathrm{pot}} \mathrm{t}^{-1}\right) \\
\text { after every cutting with same oil dilution }\end{array}$ \\
\hline $\mathbf{T}_{8}$ & $\begin{array}{l}\text { Infested soil }+ \text { cuts dipped }(10 \mathrm{~min}) \text { before planting in peppermint oil }(700 \mathrm{ppm}) \text { and sprayed }\left(5 \mathrm{ml}^{\mathrm{pot}}{ }^{-1}\right) \\
\text { after every cutting with same oil dilution }\end{array}$ \\
\hline $\mathbf{T}_{9}$ & $\begin{array}{l}\text { Infested soil }+ \text { cuts dipped }(10 \mathrm{~min}) \text { before planting in basil oil }(300 \mathrm{ppm}) \text { and sprayed }\left(5 \mathrm{ml} \mathrm{pot}^{-1}\right) \text { after } \\
\text { every cutting with same oil dilution }\end{array}$ \\
\hline $\mathbf{T}_{10}$ & $\begin{array}{l}\text { Infested soil + cuts dipped }(10 \mathrm{~min}) \text { before planting in basil oil }(500 \mathrm{ppm}) \text { and sprayed }\left(5 \mathrm{ml} \mathrm{pot}^{-1}\right) \text { after } \\
\text { every cutting with same oil dilution }\end{array}$ \\
\hline $\mathbf{T}_{11}$ & $\begin{array}{l}\text { Infested soil }+ \text { cuts dipped }(10 \mathrm{~min}) \text { before planting in basil oil }(700 \mathrm{ppm}) \text { and sprayed }\left(5 \mathrm{ml} \mathrm{pot}^{-1}\right) \text { after } \\
\text { every cutting with same oil dilution }\end{array}$ \\
\hline
\end{tabular}

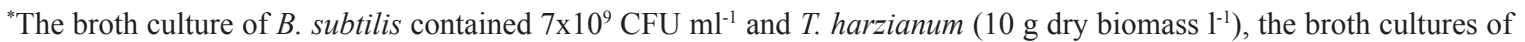
the two microbes were diluted ten folds before dibbing or spraying

${ }^{* *}$ Using tween 80 as emulsifier

TABLE 2. Some morphological characters of M. phaseolina isolate.

\begin{tabular}{ll}
\hline Character & Description \\
\hline Colony color & Blackish grey \\
Feathery & ++++ \\
Radial growth after 7 days & $90 \mathrm{~mm}$ \\
Sclerotia shape & Oblong shape with irregular edges \\
Sclerotia size & $15.2-16.6 \mu \mathrm{m}$ \\
\hline
\end{tabular}

extremely small, jet-black fungal structures called microsclerotia will be found embedded in the diseased tissue microsclerotia are usually so numerous that they resemble charcoal dust.

Antagonistic activity of bacterial strain and $T$.

Env. Biodiv. Soil Security Vol. 2 (2018) harzianum against M. phaseolina

Among the bacterial strains used in this study, T. harzianum and B. subtilis recorded the highest antagonistic effect 67.5 and $62.5 \%$ against the fungal pathogen (M. phaseolina), respectively, compared to the other bioagents under studying 
TABLE 3. Effect of different microorganisms in growth inhibition of M. phaseolina using dual culture techniques.

\begin{tabular}{lcc}
\hline Bio control agents & Radial growth of pathogen $(\mathbf{m m})$ & Reduction $\%$ \\
\hline Control & 40 & - \\
B. polymixa & 20 & 50 \\
B. circulance & 25 & 37.5 \\
B. Subtilis & 15 & 62.5 \\
T. harzianum & 13 & 67.5 \\
\hline LSD 0.01 & & $1.9^{* *}$ \\
\hline
\end{tabular}
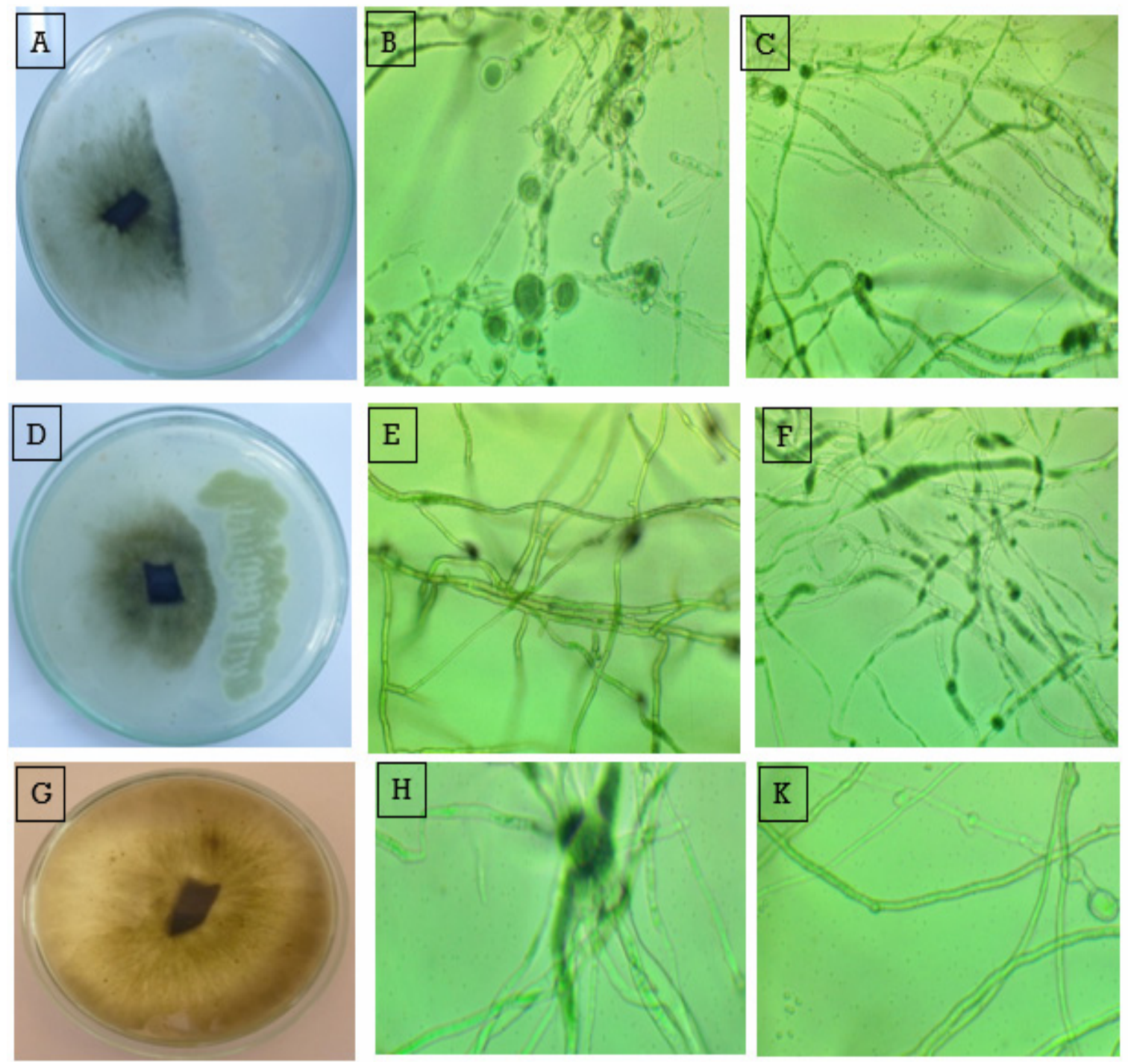

Fig. 1. The antagonistic effect between (A) M. phaseolina and B. Subtilis (B) Light microscope image $\mathrm{x} 400$ of pathogen growth edge toward $B$. Subtilis (C) Light microscope image $x 400$ of un affected pathogen growth edge (D) M. phaseolina and Trichoderma(E) Light microscope image $x 400$ of pathogen growth edge toward Trichoderma (F) Light microscope image $\mathbf{x} 400$ of un affected pathogen growth edge (G)M. phaseolina $(\mathrm{H})$ fungal mycelia affected by peppermint oil (K)fungal mycelia affected by basil oil. 
the dual culture techniques as shown in Table 3 and Fig. 1.

Antagonistic activity of different essential oils concentrations against M. phaseolina

As shown in Table 4, the effect of different concentrations of essential oils against $M$. phaseolina after $24 \mathrm{~h}$ was zero except in case of (Spearmint) and (Peppermint) and at the same concentration the highest inhibition ratios were achieved after $48 \mathrm{~h}$ and declined again after $72 \mathrm{~h}$. While, at intermediate and high concentrations, the highest inhibition rations were achieved after $24 \mathrm{~h}$ and began to decrease during the next
$48 \mathrm{~h}$ of incubation. In general, it was observed that growth reduction ratios were increased with the increase of essential oil concentration especially after $48 \mathrm{~h}$ incubation. Among the treatments, treatment with (Peppermint) recorded the highest reduction in growth while treatment with (Marjoram) had no effect on the growth of pathogen. The variations in antifungal activity among the tested essential oils in this study may be attributed to the respective composition of the herbal essential oil, the structural configuration of the constituent components and their functional groups and possible synergistic interactions between components (Dorman, 2000).

TABLE 4. Effect of different concentrations of essential oils $\left(\mu \mathrm{L}\right.$ plate $\left.\mathrm{e}^{-1}\right)$ on growth of M. phaseolina.

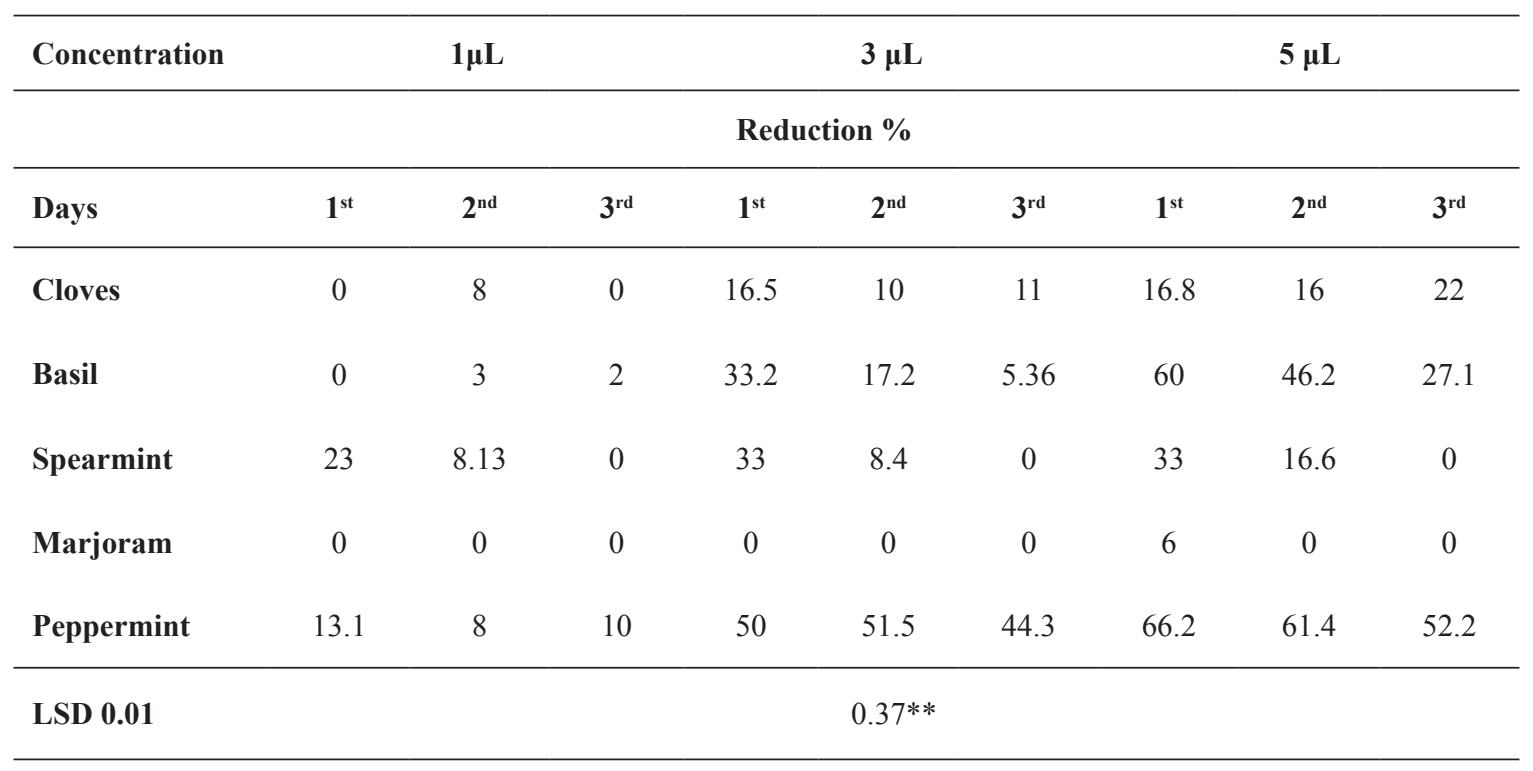

\section{Plant growth promoting}

Positive results of plant growth promoting produced by the most two antagonistic effect microbes $B$. Subtilis and $T$. harzianum for hydrolytic enzymes (chitinase and protease) in addition to cytotoxic agent ( $\mathrm{HCN}$ ) and compounds responsible for iron starvation (Siderophore). Also, the two microbes show the ability to form plant growth promoting agent Indole Acetic Acid (IAA).

\section{Greenhouse experiment}

Plant height and number of branches

As shown in Table 5, the dipping and foliar spray with the varied biocontrol agents and essential oil concentrations on plant height and number of branches gave significant differences than control in both seasons under infested soils.
Generally, in all treatments, plant height was decreased with increasing number of cuts which the average maximum of height plant was attained at $\mathrm{T}_{5}$ treatment (infested + dipping for $30 \mathrm{~min}$ and spraying with $5 \mathrm{ml} \mathrm{pot}^{-1}$ with $T$. harzianum (10 $\mathrm{g}$ dry biomass $\mathrm{1}^{-1}$ ), which was 50.20 and 51.20 $\mathrm{cm}$, followed by $\mathrm{T}_{4}$ treatment (infested + dipping for $30 \mathrm{~min}$ and spraying with $5 \mathrm{ml} \mathrm{pot}^{-1}$ with $B$. subtilis $\left(7 \times 10^{9} \mathrm{CFU} \mathrm{ml}^{-1}\right)$, which was 50.10 and $48.20 \mathrm{~cm}$ compared to different control treatments at the all cuts during 2017 and 2018 seasons, respectively. Where, the average maximum of number of branches were recorded 13 and 13.3 for $\mathrm{T}_{4}$ treatment and 12.8 and 12.5 for $\mathrm{T}_{5}$ treatment compared to different control treatments during 2017 and 2018 seasons, respectively. 
TABLE 5. Effect of biocontrol agents (B. subtilis and T. harzianum) and different essential oil concentrations on plant height and number of branchesof geranium plantsduring 2017 and 2018 seasons.

\begin{tabular}{|c|c|c|c|c|c|c|}
\hline \multicolumn{7}{|c|}{ Plant height (cm) } \\
\hline \multirow{2}{*}{ Treatments } & \multicolumn{3}{|c|}{2017} & \multicolumn{3}{|c|}{2018} \\
\hline & $1^{\text {st }}$ cut & $2^{\text {nd }}$ cut & $3^{\text {rd }}$ cut & $1^{\text {st }}$ cut & $2^{\text {nd }}$ cut & $3^{\text {rd }}$ cut \\
\hline $\mathrm{T} 1$ & $54.6^{\mathrm{bc}}$ & $37.7^{\mathrm{ab}}$ & $24.3^{c}$ & $53.0^{\text {bd }}$ & 39.3 & $24.7^{\mathrm{c}}$ \\
\hline $\mathrm{T} 2$ & $47.0^{\mathrm{c}}$ & $34.7^{\mathrm{b}}$ & $17.3^{\mathrm{d}}$ & $48.3^{\mathrm{d}}$ & 36.3 & $16.7^{\mathrm{d}}$ \\
\hline $\mathrm{T} 3$ & $67.7^{\mathrm{ab}}$ & $44.0^{\mathrm{ab}}$ & $25.0^{b c}$ & $64.7 \mathrm{ac}$ & 43.7 & $24.0^{\mathrm{c}}$ \\
\hline $\mathrm{T} 4$ & $70.7^{\mathrm{a}}$ & $48.0^{\mathrm{a}}$ & $31.7^{\mathrm{a}}$ & $67.3^{\mathrm{ab}}$ & 45.7 & $31.7^{\mathrm{ab}}$ \\
\hline $\mathrm{T} 5$ & $74.7^{\mathrm{a}}$ & $45.0^{\mathrm{ab}}$ & $31.0^{a b}$ & $75.0^{\mathrm{a}}$ & 48.3 & $31.3^{\mathrm{ab}}$ \\
\hline T6 & $50.3^{c}$ & $38.3^{\mathrm{ab}}$ & $23.3^{c}$ & $50.0^{\mathrm{cd}}$ & 39.3 & $24.0^{\mathrm{c}}$ \\
\hline $\mathrm{T} 7$ & $56.7^{\mathrm{c}}$ & $37.7^{\mathrm{ab}}$ & $31.7^{\mathrm{a}}$ & 54.7 bd & 34.7 & $31.7^{a b}$ \\
\hline $\mathrm{T} 8$ & $58.3^{\mathrm{bc}}$ & $37.3^{\mathrm{ab}}$ & $26.7^{\mathrm{ac}}$ & $55.3 \mathrm{bd}$ & 40.3 & $26.3^{b c}$ \\
\hline T9 & $52.0^{\mathrm{c}}$ & $39.3^{a b}$ & $26.0^{\mathrm{ac}}$ & $56.3 \mathrm{bd}$ & 43.3 & $25.7^{\mathrm{c}}$ \\
\hline $\mathrm{T} 10$ & $58.7^{\mathrm{bc}}$ & $43.0^{\mathrm{ab}}$ & $30.7^{\mathrm{ab}}$ & $57.3^{\mathrm{bd}}$ & 43.0 & $33.0^{\mathrm{a}}$ \\
\hline $\mathrm{T} 11$ & $67.3^{\mathrm{ab}}$ & $39.3^{\mathrm{ab}}$ & $27.0 \mathrm{ac}$ & $61.7^{\text {bd }}$ & 42.0 & $26.0^{\mathrm{bc}}$ \\
\hline L.S.D 0.05 & $8.23^{* *}$ & $7.56^{*}$ & $4.09^{* *}$ & $9.6^{* *}$ & n.s & $3.97^{* *}$ \\
\hline \multicolumn{7}{|c|}{ No. branches plant ${ }^{-1}$} \\
\hline \multirow{2}{*}{ Treatments } & \multicolumn{3}{|c|}{2017} & \multicolumn{3}{|c|}{2018} \\
\hline & $1^{\text {st }}$ cut & $2^{\text {nd }}$ cut & $3^{\text {rd }}$ cut & $1^{\text {st }}$ cut & $2^{\text {nd }}$ cut & $3^{\text {rd }}$ cut \\
\hline $\mathrm{T} 1$ & $4.0^{\mathrm{d}}$ & $14.3^{\mathrm{a}}$ & 12.3 & $4.0^{\mathrm{cd}}$ & $14.0^{\mathrm{a}}$ & $12.7^{\mathrm{ab}}$ \\
\hline $\mathrm{T} 2$ & $3.0^{\mathrm{d}}$ & $11.7^{\mathrm{a}}$ & 10.7 & $2.7^{\mathrm{d}}$ & $11.7^{\mathrm{a}}$ & $9.7^{\mathrm{b}}$ \\
\hline $\mathrm{T} 3$ & $13.0^{\mathrm{ab}}$ & $7.0^{\mathrm{b}}$ & 11.3 & $12.7^{\mathrm{ab}}$ & $7.3^{b}$ & $10.7^{\mathrm{ab}}$ \\
\hline $\mathrm{T} 4$ & $14.0^{\mathrm{a}}$ & $12.7^{\mathrm{a}}$ & 13.0 & $14.3^{\mathrm{a}}$ & $13.0^{\mathrm{a}}$ & $12.7^{\mathrm{ab}}$ \\
\hline $\mathrm{T} 5$ & $10.7^{\mathrm{b}}$ & $14.0^{\mathrm{a}}$ & 13.7 & $11.3^{\mathrm{b}}$ & $13.7^{\mathrm{a}}$ & $12.7^{a b}$ \\
\hline T6 & $5.0^{\mathrm{cd}}$ & $12.3^{\mathrm{a}}$ & 12.3 & $4.0^{\mathrm{cd}}$ & $13.0^{\mathrm{a}}$ & $13.0^{\mathrm{ab}}$ \\
\hline $\mathrm{T} 7$ & $5.3^{\mathrm{cd}}$ & $12.7^{\mathrm{a}}$ & 12.7 & $5.7^{\mathrm{cd}}$ & $12.3^{\mathrm{a}}$ & $13.0^{\mathrm{ab}}$ \\
\hline $\mathrm{T} 8$ & $3.0^{\mathrm{d}}$ & $12.0^{\mathrm{a}}$ & 11.7 & $2.7^{\mathrm{d}}$ & $12.7^{\mathrm{a}}$ & $11.7^{\mathrm{ab}}$ \\
\hline T9 & $3.0^{\mathrm{d}}$ & $13.7^{\mathrm{a}}$ & 12.7 & $3.3^{d}$ & $14.0^{\mathrm{a}}$ & $13.0^{a b}$ \\
\hline $\mathrm{T} 10$ & $5.3^{\mathrm{cd}}$ & $12.7^{\mathrm{a}}$ & 14.0 & $5.3^{\mathrm{cd}}$ & $13.3^{\mathrm{a}}$ & $14.7^{\mathrm{a}}$ \\
\hline $\mathrm{T} 11$ & $8.0^{\mathrm{c}}$ & $10.7^{\mathrm{a}}$ & 12.3 & $6.7^{\mathrm{c}}$ & $10.3^{\mathrm{a}}$ & $12.0^{\mathrm{ab}}$ \\
\hline L.S.D 0.05 & $2.65^{* *}$ & $7.56^{*}$ & n.s & $2.04^{* *}$ & $2.19^{* *}$ & $2.41^{*}$ \\
\hline
\end{tabular}

For more details about the treatments, please refer to Table 1

Leaves to stem ratio and Herb yield fresh weight

Table 6 depicted the results of leaves to stem ratio and herb yield fresh weight of geranium plant. Highly significant variations in the above mentioned parameters were observed under both of dipping and spraying with different treatments with biocontrol agents and essential oils. For leaves to stem ratio, an increase was observed with increasing the number of cuts and the same trend was also exhibited with the high concentration from essential oil treatments. For example, at the third cut during 2017 and 2018 growing season, $\mathrm{T}_{11}$ treatment (infested + dipping for $10 \mathrm{~min}$ and spraying with $5 \mathrm{ml}$ pot $^{-1}$ with basil $(700 \mathrm{ppm})$, recorded the highest values in leaves to stem ratio 6.96 and 6.74 compared to the other concentrations treatment, respectively. For herb yield fresh weight parameter, all treatments showed that the first cut attained the highest fresh weight of herb yield then decreased in the other cuts during 2017 and 2018 seasons. Also, biocontrol agent treatments (B. subtilis and $T$. harzianum) recorded the highest values more than different essential oil and control treatments.

\section{Infection percentage}

Infection percentage of geranium plants as affected by biocontrol agents (B. subtilis and $T$. harzianum) and different essential oil concentrations are illustrated in Table 7. Disease severity was reduced as a result for microbial and essential oils application compared with the control. Under soil infested with M. phaseolina, it was noticed that dipping for $30 \mathrm{~min}$ and spraying with $5 \mathrm{ml} \mathrm{pot}^{-1}$ with $T$. harzianum treatment $\left(\mathrm{T}_{5}\right)$ was the most reduction for biocontrol agent. But for essential oils, $\mathrm{T}_{9}$ treatment (dipping for $10 \mathrm{~min}$ and spraying with $5 \mathrm{ml} \mathrm{pot}^{-1}$ with basil (300 ppm), was the most reduction treatment compared with the control at the two growing seasons.

\section{Oil percentage}

Among biocontrol agents (B. subtilis 
TABLE 6. Effect of biocontrol agents (B. subtilis and T. harzianum) and different essential oil concentrations on leaves to stem ratio and herb yield Fresh weight of geranium plants during 2017 and 2018 seasons.

\begin{tabular}{|c|c|c|c|c|c|c|}
\hline \multicolumn{7}{|c|}{ Leaves to stem ratio } \\
\hline \multirow{2}{*}{ Treatments } & \multicolumn{3}{|c|}{2017} & \multicolumn{3}{|c|}{2018} \\
\hline & $1^{\text {st }}$ cut & $2^{\text {nd }}$ cut & $3^{\text {rd }}$ cut & $1^{\text {st }}$ cut & $2^{\text {nd }}$ cut & $3^{\text {rd }}$ cut \\
\hline $\mathrm{T} 1$ & $2.38^{\mathrm{ab}}$ & $4.21^{\mathrm{ab}}$ & $4.51^{\mathrm{cde}}$ & $2.42^{\mathrm{ab}}$ & $4.41^{\mathrm{a}}$ & $4.47^{\text {cde }}$ \\
\hline $\mathrm{T} 2$ & $2.31^{\mathrm{ab}}$ & $4.58^{\mathrm{ab}}$ & $5.00^{\mathrm{cd}}$ & $2.56^{\mathrm{a}}$ & $4.65^{\mathrm{a}}$ & $4.83^{\mathrm{bcd}}$ \\
\hline $\mathrm{T} 3$ & $2.03^{\mathrm{bc}}$ & $3.42^{\mathrm{b}}$ & $4.43^{\mathrm{cde}}$ & $1.94^{\mathrm{bcd}}$ & $3.64^{\mathrm{a}}$ & $4.68^{\mathrm{bcde}}$ \\
\hline $\mathrm{T} 4$ & $1.86^{\mathrm{bc}}$ & $3.80^{\mathrm{ab}}$ & $4.43^{\mathrm{cde}}$ & $1.82^{\mathrm{cd}}$ & $3.82^{\mathrm{a}}$ & $4.39^{\text {cde }}$ \\
\hline $\mathrm{T} 5$ & $1.89^{\mathrm{bc}}$ & $4.02^{\mathrm{ab}}$ & $4.13^{\mathrm{de}}$ & $1.92^{\mathrm{bcd}}$ & $4.04^{\mathrm{a}}$ & $4.21^{\mathrm{cde}}$ \\
\hline T6 & $2.22^{\mathrm{abc}}$ & $4.49^{\mathrm{ab}}$ & $3.66^{\mathrm{de}}$ & $2.17^{\mathrm{abc}}$ & $4.53^{\mathrm{a}}$ & $3.66^{\mathrm{de}}$ \\
\hline $\mathrm{T} 7$ & $2.85^{\mathrm{a}}$ & $4.53^{\mathrm{ab}}$ & $6.93^{\mathrm{a}}$ & $2.69^{a}$ & $4.69^{\mathrm{a}}$ & $6.54^{\mathrm{a}}$ \\
\hline $\mathrm{T} 8$ & $2.27^{\mathrm{ab}}$ & $4.85^{\mathrm{a}}$ & $6.29^{\mathrm{ab}}$ & $2.32^{\mathrm{abc}}$ & $4.94^{\mathrm{a}}$ & $6.02^{\mathrm{ab}}$ \\
\hline T9 & $2.04^{\mathrm{bc}}$ & $3.75^{\mathrm{ab}}$ & $3.41^{\mathrm{e}}$ & $1.99^{\mathrm{bcd}}$ & $3.88^{\mathrm{a}}$ & $3.13^{\mathrm{e}}$ \\
\hline $\mathrm{T} 10$ & $2.02^{\mathrm{bc}}$ & $4.08^{\mathrm{ab}}$ & $5.64^{\mathrm{bc}}$ & $1.97^{\mathrm{bcd}}$ & $4.26^{\mathrm{a}}$ & $5.46^{\mathrm{abc}}$ \\
\hline $\mathrm{T} 11$ & $1.49^{\mathrm{c}}$ & $4.22^{\mathrm{ab}}$ & $6.96^{\mathrm{a}}$ & $1.53^{\mathrm{d}}$ & $4.43^{\mathrm{a}}$ & $6.74^{\mathrm{a}}$ \\
\hline \multirow[t]{2}{*}{ L.S.D 0.05} & $0.46^{* *}$ & $0.81^{*}$ & $0.93^{* *}$ & $0.36^{* *}$ & n.s & $1.08^{* *}$ \\
\hline & \multicolumn{6}{|c|}{ Herb yield fresh weight $\left(\right.$ g plant $\left.^{-1}\right)$} \\
\hline \multirow{2}{*}{ Treatments } & \multicolumn{3}{|c|}{2017} & \multicolumn{3}{|c|}{2018} \\
\hline & $1^{\text {st }} \mathrm{cut}$ & $2^{\text {nd }}$ cut & $3^{\text {rd }}$ cut & $1^{\text {st }} \mathrm{cut}$ & $2^{\text {nd }}$ cut & $3^{\text {rd }}$ cut \\
\hline $\mathrm{T} 1$ & $78.9^{\text {ce }}$ & $76.33^{c}$ & $39.10^{\mathrm{e}}$ & $79.00^{\text {ce }}$ & $77.53^{\mathrm{cd}}$ & $38.40^{\mathrm{f}}$ \\
\hline $\mathrm{T} 2$ & $68.8^{\mathrm{e}}$ & $73.70^{c}$ & $30.40^{\mathrm{f}}$ & $71.66^{\mathrm{e}}$ & $72.73^{\mathrm{d}}$ & $30.27^{\mathrm{g}}$ \\
\hline $\mathrm{T} 3$ & $95.9^{\mathrm{b}}$ & $54.00^{\mathrm{d}}$ & $45.6^{\mathrm{de}}$ & $96.00^{\mathrm{b}}$ & $57.33^{\mathrm{e}}$ & $47.50^{\mathrm{e}}$ \\
\hline $\mathrm{T} 4$ & $113.5^{\text {a }}$ & $91.33^{\mathrm{b}}$ & $69.3^{\mathrm{ab}}$ & $114.64^{\mathrm{a}}$ & $90.43^{\mathrm{b}}$ & $68.6^{\mathrm{ab}}$ \\
\hline T5 & $108.8^{\text {a }}$ & $103.78^{a}$ & $73.4^{\mathrm{a}}$ & $110.44^{\text {a }}$ & $104.83^{\mathrm{a}}$ & $72.40^{\mathrm{a}}$ \\
\hline T6 & $73.8 \mathrm{de}$ & $77.40^{\mathrm{c}}$ & $58.7 \mathrm{bc}$ & 74.28 de & $80.40^{b d}$ & $56.9^{\mathrm{cd}}$ \\
\hline $\mathrm{T} 7$ & 75.7 de & $82.53^{b c}$ & $65.10^{\mathrm{ac}}$ & $78.11^{\mathrm{ce}}$ & $84.17^{b c}$ & $62.63^{b c}$ \\
\hline $\mathrm{T} 8$ & $84.4^{\text {bd }}$ & $82.27^{b c}$ & $60.0^{\mathrm{bc}}$ & 84.68 bd & 83.53 bc & $58.5^{\mathrm{cd}}$ \\
\hline T9 & $84.3^{\text {bd }}$ & $74.47^{\mathrm{c}}$ & $54.3^{\mathrm{cd}}$ & $84.60^{b d}$ & $75.80^{\mathrm{cd}}$ & $52.30^{\mathrm{de}}$ \\
\hline $\mathrm{T} 10$ & $88.2^{b c}$ & $82.93 \mathrm{bc}$ & $54.5^{\mathrm{cd}}$ & $88.71^{\text {bc }}$ & 84.87 bc & $54.7^{\mathrm{ce}}$ \\
\hline $\mathrm{T} 11$ & $90.6^{b c}$ & $87.80^{\mathrm{b}}$ & $63.1^{\mathrm{bc}}$ & $89.17^{b c}$ & $90.43^{\mathrm{b}}$ & $63.7^{b c}$ \\
\hline L.S.D 0.05 & $8.68^{* *}$ & $7.13^{* *}$ & $7.52^{* *}$ & $8.04^{* *}$ & $7.1^{* *}$ & $6.36^{* *}$ \\
\hline
\end{tabular}

For more details about the treatments, please refer to Table 1

TABLE 7. Effect of biocontrol agents (B. subtilis and T. harzianum) and different essential oil concentrations on infection percentage of geranium plants during 2017 and 2018 seasons.

\begin{tabular}{ccc}
\hline \multirow{2}{*}{ Treatments } & \multicolumn{2}{c}{ Infection \% } \\
\cline { 2 - 3 } & $\mathbf{2 0 1 7 ^ { 2 }}$ & $\mathbf{2 0 1 8}$ \\
\hline T1 & $0.0^{\mathrm{b}}$ & $0.0^{\mathrm{c}}$ \\
T3 & $72.2^{\mathrm{a}}$ & $66.7^{\mathrm{a}}$ \\
T4 & $22.2^{\mathrm{b}}$ & $27.8^{\mathrm{b}}$ \\
T5 & $5.6^{\mathrm{b}}$ & $5.6^{\mathrm{bc}}$ \\
T6 & $5.6^{\mathrm{b}}$ & $0.0^{\mathrm{c}}$ \\
T7 & $5.6^{\mathrm{b}}$ & $5.6^{\mathrm{bc}}$ \\
T8 & $5.6^{\mathrm{b}}$ & $5.6^{\mathrm{bc}}$ \\
T9 & $11.1^{\mathrm{b}}$ & $22.2^{\mathrm{bc}}$ \\
T10 & $5.6^{\mathrm{b}}$ & $0.0^{\mathrm{c}}$ \\
T11 & $11.1^{\mathrm{b}}$ & $16.7^{\mathrm{bc}}$ \\
\hline L.S.D 0.05 & $16.7^{\mathrm{b}}$ & $22.2^{\mathrm{bc}}$ \\
\hline
\end{tabular}

For more details about the treatments, please refer to Table 1

Env. Biodiv. Soil Security Vol. 2 (2018) 
and T. harzianum) and different essential oil concentrations (peppermint and basil). $T$. harzianum had maximum positive effect and increased of oil \%, which recorded $0.45,0.30$ and $0.38 \%$ at 2017 season and $0.47,0.31$ and $0.39 \%$ at 2018 season for $1^{\text {st }}, 2^{\text {nd }}$ and $3^{\text {rd }}$ cut, more than other treatments and control, respectively (Table 8).

\section{Discussion}

Biological control introduces several advantages over other types of pathogen control such as: high specificity against targeted pathogens, low cost of production and application as well as ecofriendly. The antagonistic mechanisms through which biological control agent affect pathogens community are variable and not always clear, but generally may be related to one of the following: (1) direct parasitism leading to death of the pathogen; (2) competition on nutrients and space and (3) production of cytotoxic compounds such as antibiotics or toxic volatiles (Heydari and Pessarakli 2010; Omara et al. 2018).

For antagonistic activity of bacterial straina gainst $M$. phaseolina. An inhibitory zone was detected suggesting the presence of fungi static metabolites produced by $B$. subtilis. It has been reported that $B$. subtilis can produce several antifungal metabolites such as subtiline, bacitracin, bacillin and bacillomycin, which belong to the iturine family (Alippi and Mónaco, 1994). The antifungal activity of B. subtilis may be also due to the production of antibiotics
(Silva et al. 2001). Also, hydrolytic enzymes such as chitinase and glucanase produced by Bacillus sp. play a significant role in fungal growth control through degradation of fungal cell wall (Chet et al. 1990; Ashwini and Srividya 2014).

In the current study B. subtilis and T.harzianum were able to produce some hydrolytic enzymes like chitinase and protease responsible for fungal cell lytic leading to inhibition of growth, this can be clearly observed in Fig 1b, c) where in case of $B$. subtilis the part of fungal growth toward bacterial growth was pushed to produce sclerotia earlier than the other side of growth which not subjected to the effect of growing bacteria leasing to shorten its life cycle. The suggested strategy used in this case may by the production of siderophores leading to iron starvation which affect pathogen growth. Previous studies have demonstrated that Trichoderma species can be used as a biocontrol agent in controlling a number of plant diseases with high efficacy (Kucuk and Kivanc 2003; Omara et al. 2017, 2018; Elkhwaga et al. 2018). Also, the light microscope image illustrates the possible mechanism used by the Trichoderma to inhibit fungal growth where the affected pathogen mycelia appeared empty from cytoplasm and its component in addition to loss of septation, so it is likely that the mechanism involved in this case is related to the hydrolytic enzymes.

Essential oils are promising antifungal agents that can be easily produced and purchased. The potential of these oils can be related to the activity

TABLE 8. Effect of biocontrol agents (B. subtilis and T. harzianum) and different essential oil concentrations on oil percentage of geranium plants during 2017 and 2018 seasons.

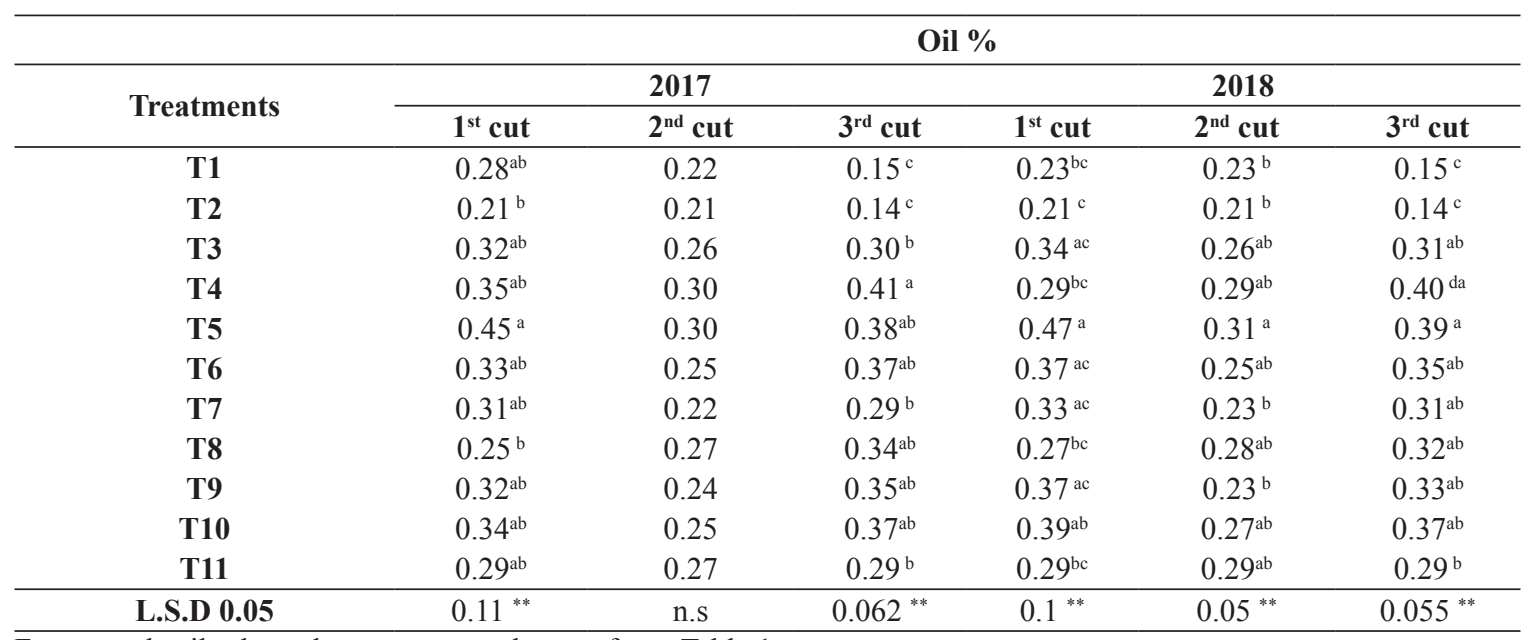

For more details about the treatments, please refer to Table 1 
of many ingredients such as phenols, thymol and carvacrol. Several studies (Carmo et al. 2008; Gallucci et al. 2014; Fayaz et al. 2017; Shabana et al. 2017; Elkhwaga et al. 2018) considered phenol compounds as the most effective ingredient with the highest antifungal activity among all terpene compounds of essential oils. The suggested mechanism is that monoterpene alcohols disrupt the permeability of the fungal plasma membrane and inhibit the respiration process on mitochondrial membrane (Cox et al. 2000; Deba et al. 2008). There are several studies about improving growth dynamics and increased availability of nutrients in the rhizosphere (Patten and Glick 2002). It is clearly observed that B.subtilis and T. harzianum treatments and essential oils caused sharp increase in vegetative growth such as plant height, branches, leaves number, and oil yield (Lu et al. 2017; Sadeghi et al. 2017; Omara et al. 2018).

\section{Conclusion}

In general, disease severity was reduced as a result of microbial and essential oils application compared with the control. The average reduction of pathogen infection was about $92 \%$ compared to infested control in most treatments except in case of treatment with some concentrations of essential oils. Microbial treatment not only reduced the fungal infection but also enhanced plant growth parameters including both vegetative growth and oil yield. It is clearly observed that B.subtilis and T. harzianum as well as essential oils treatments caused sharp increase in plant growth such as plant height, branches, leaves number, and oil yield in both seasons.

\section{Acknowledgments}

Authors thank the outstanding contribution of Dr. Nasr Ghazy (Plant Pathology Research Institute, Agricultural Research Center, Egypt) and stuff members of Microbiology Lab at Sakha Agricultural Research Station, Agricultural Research Center for their help.

\section{References}

Alippi A. and Mónaco C. (1994). Antagonismoin vitro de especies de Bacillus contra Sclerotiumrolfsiiy Fusariumsolani. Revista de la Facultad de Agronomía, La Plata 70, p. 91-95.

Allen, O. N. (1959) Experiments in Soil Bacteriology. Burgess pub. Co., Ninn, Minnesota

Env. Biodiv. Soil Security Vol. 2 (2018)
Ashwini N. and Srividya S. (2014) Potentiality of Bacillus subtilis as biocontrol agent for management of anthracnose disease of chilli caused by Colletotrichumgloeosporioides OGC1. 3 Biotech; 4, 127-136.

Barnett H. L. and Hunter B. B. (1972) Illustrated Genera of Imperfect Fungi, Burgress Publishing Company, Minneapolis, Minn, USA.

Boyraz N. andOzcan, M. (2006) Inhibition of phytopathogenic fungi by essential oil, hydrosol, ground material and extract of summer savory (SaturejahortensisL.) growing wild in Turkey. Inter. J. Food Microbiology, 107, 238-242.

Carmo E.S., de Oliveira Lima E., and de Souza, E.L. (2008) The potential of Origanum vulgare L. (Lamiaceae) essential oil in inhibiting the growth of some food-related Aspergillus species. Braz. J. Microbiol. 39, 362-367.

Chet I., Ordentlich A., Shapira R. and Oppenheim A.B. (1990) Mechanisms of biocontrol of soil borne plant pathogens by Rhizobacteria.Plant Soil. 129, 85-92. http://dx.doi.org/10.1007/BF00011694.

Cox D., Mann M., Markham L., Bell C., Gustafson E., Warmington R. and Wyllie G. (2000) The mode of antimicrobial action of the essential oil of Melaleucaalternifolia (tea tree oil). J. Appl. Microbiol. 88, 170-175.

Deans, S.G. and Svoboda, K.P. (1990) Biotechnology and bioactivity of culinary and medicinal plants. AgBiotech. News Inform., 2, 211-216.

Deba F., Xuan T., Yasuda M. and Tawata S. (2008) Chemical composition and antioxidant, antibacterial and antifungal activities of the essential oils from Bidenspilosa Linn.var. Radiata. Food Control. 19, 346-352

Dorman H. and Deans S. (2000) Antimicrobial agents from plants: antibacterial activity of plant volatile oils. J. Appl. Microbiol, 88, 308-316.

Eiasu B.K., Steyn J.M. and Soundy P. (2012) Physiomorphological response of rose-scented geranium (Pelargonium spp.) to irrigation frequency. S. Afr. J. Bot.78, 96-103.

Elkhwaga A.A., Elzaawely A. A., Draz I.S., Ismail A.A. and El-Zahaby H.M. (2018) Potential of Some Plant Extracts in Controlling Wheat Leaf Rust Caused by Pucciniatriticina Eriks. Env.Biodiv. Soil Security Vol. 2, pp. 95 - 102

Elsharkawy, M. M. and El-Sawy, M. M. (2015) Control 
of bean common mosaic virus by plant extracts in bean plants. Inter. J. Pest Management, 61, 54-59.

Fang X.L. Phillips D., Li H., Sivasithamparam K. and Barbetti M.J. (2011) Comparisons of virulence of pathogens associated with crown and root diseases of strawberry in Western Australia with special reference to the effect of temperature. Sci. Hortic.131, 39e48.

Fayaz, M., Bhat, M. H., Fayaz, M., Kumar, A. and Jain, A. K. (2017) Antifungal activity of Lantana camara L. leaf extracts in different solvents against some pathogenic fungal strains. Pharmacologia, $\mathbf{8}$, $105-112$.

Fokkema N.J. (1973) The role of saprophytic fungi in antagonism against Derchslerasorokaniana(Hel minthosporiumsativum) on agar plates and on rye leaves with pollen. Physiological Plant Pathology 3, 95-205.

Gallucci M.N., Carezzano M.E., de Las M., Oliva M., Demo M.S., Pizzolitto R.P., Zunino M.P., Zygadlo J.A. andDambolena J.S. (2014) In Vitro activity of natural phenolic compounds against fluconazole-resistant Candida species. A quantitative structure-activity relationship analysis. J. Appl. Microbiol., http:// dx.doi.org/10.1111/jam.12432

Gohel V., Singh A., Vimal M., Ashwini P. and Chhatpar H.S. (2006) Bioprospecting and antifungal potential of chitinolytic microorganisms. Afr. J. Biotechnol. 5 (2), 54-72.

Gupta G.K., Sharma S.K. and Ramteke R. (2012) Biology, epidemiology and management of the pathogenic fungus Macrophominaphaseolina (Tassi) Goid with special reference to charcoal rot of soybean (Glycine $\max$ (L.) Merrill. J. Phytopathol. 160, 167-180.

Heydari A. andPessarakli M. (2010) A review on biological control of fungal plant pathogens using microbial antagonists. J. Biol. Sci. 10, 273-290.

Hussain S. and Ghaffar, A. (1990) Biological control of Macrophominaphaseolina charcoal rot of sunflower and mung bean. J. Phytopatho., 130, 157-160.

Ivanova E.G., Doronina N.V. and Trotsenko I. U.A. (2001) Aerobic methylobacteria are capable of synthesizing auxins. Mikrobiologia 70, 452-458.

Kaur S., Dhillon G.S. and Chauhan V.B. (2013)
Morphological and pathogenic variability in Macrophominaphaseolina isolates of pigeonpea (Cajanuscajan L.) and their relatedness using principle component analysis. Archives of Phytopathology and Plant Protection, 46, 19, 2281-2293, http://dx.doi.org/10.1080/03235408.2 $\underline{013.792538 .}$.

Keshavarz-Tohid, V., Taheri, P., Muller, D., PrigentCombaret, C., Vacheron, J., Taghavi, S.M., SaeedTarighi, S. and Moëenne-Loccoz, Y. (2017) Phylogenetic diversity and antagonistic traits of root and rhizosphere pseudomonads of bean from Iran for controlling Rhizoctoniasolani. Research in Microbiology, 168, 760-772

Kucuk C. and Kivanc M. (2003) Isolation of Trichodermaspp. and determination of their antifungal, biochemical and physiological features. Turkish J. Biology 27, 247 - 253.

Landa B.B., Hervás A., Bettiol W. and Jiménezdiaz R.M. (1997) Antagonistic activity of bacteria from the chickpea rhizosphere against Fusariumoxysporumf.sp.ciceris. Phytoparasitica. 25(4), 305-318.

Lorck, H. (1948) Production of hydrocyanic acid by bacteria. Physiol. Plant. 1, 142-146

Lu, X., Zhou, D., Chen, X., Zhang, J., Huang, H. and Wei, L. (2017) Isolation and characterization of Bacillus altitudinis JSCX-1 as a new potential biocontrol agent against Phytophthorasojae in soybean [Glycine $\max$ (L.)Merr.]. Plant Soil; 416, 53-66. DOI 10.1007/s11104-017-3195-z

Matthews A.J. (1995) Geranium leaves for cracked nipples. Australian J. Hospital Pharmacy 25, 538539.

Meyer W. A., Sinclair J. B., and Khare M. N. (1973) Biology of Macrophominaphaseolina in soil studies with selective media," Phytopathology, 63 (5), pp. 613-620.

Mihail, J.D. (1989) Macrophominaphaseolina: spatiotemporal dynamics of inoculum and of disease in a highly susceptible crop. Phytopathology 79, 848855.

Mishra, S. K. and Raja, R. (1999) Systemic acquired resistance: a review. Annual of Agric. Res., 20, 24959.

Muthomi J.W., Otieno P.E., Chemining'wa G.N., Nderitu J.H. and Wagacha J.M., (2007) Effect of legume root rot pathogens and fungicide seed 
treatment on nodulation and biomass accumulation. J. Biol. Sci. 7 (7), 1163-1170

Naseri B. (2008) Root rot of common bean in Zanjan, Iran: major pathogens and yield loss estimates. Australas. Plant Pathol. 37 (6), 546-551

Omara A., Hauka F., Hafez A.,Nour El-Din M. and M. Kassem M. (2017) The Role of Some PGPR Strains to Biocontrol Rhizoctonia Solani in Soybean and Enhancement The Growth Dynamics and Seed Yield. Env.Biodiv. Soil Security Vol. 1,pp.47 - 59

Omara A., Nour El-Din M., Hauka F., Hafez A., ElNahrawy S., Ghazi A., Elsakhawy T. and Vincenzina F. (2018) Suppression of Rhizoctoniasolani Damping-off in Soybean (Glycine max L.) by Plant Growth Promoting Rhizobacteria Strains. Env. Biodiv.Soil Security Vol. 2, pp.39 - 49.

Patten, C. L. and Glick, B. R. (2002) Role of Pseudomonaseputidaindole acetic acid in development of the host plant root system. Appl. Environ. Microbiol., 68, 3795-3801.

Sadeghi, A., Koobaz, P., Azimi, H., Karimi, E. and Akbari, A.R. (2017) Plant growth promotion and suppression of Phytophthoradrechsleri damping-off in cucumber by cellulase-producing Streptomyces. Bio.Control., 62, 805-819. DOI 10.1007/s10526017-9838-4

Saima, M. Kuddus, Roohi, I.Z. Ahmad (2013) Isolation of novel chitinolytic bacteria and production optimization of extracellular chitinase. J. Genetic Eng. and Biotechnol. 11, 39-46

Schwyn B. and Neilands B. (1987) Uneversal chemical assay of detection and determination of siderophores. Analytical Biochem., 160, 47-56.

Shabana, Y. M., Abdalla, M. E., Shahin, A. A., ElSawy, M. M., Draz, I. S. and Youssif, A. W. (2017)
Efficacy of plant extracts in controlling wheat leaf rust disease caused by Pucciniatriticina. Egyptian J. Basic and Applied Sci., 4, 67-73.

Silva P., Montealegre J., Besoain X. and Pérez L.M. (2001) Efecto de bacterias biocontr oladorassobregerminación y desarrollo de tomate y sobreexpresión de proteínas de defensa. In: Congreso Sociedad Chilena de Fitopatología. (XI, $4^{\text {th }}-5^{\text {th }}$ December, 2001, Santa Cruz, Chile). Abstracts, p. 29.

Sjodahl J, Emmer A, Vincent J and Roeraade J. (2002) Characterization of proteinases from Antarctic krill (Euphausiasuperba). Protein Expression and Purification. 26:153-161.

Sreeramulu, A., Arunakumari, M. and Reddy, P. L. N. (2017) Antifungal Activity of wild sage (Lantana camara) against Colletotrichumfalcatum. Inter J. Current Microbiology and Applied Sci., 6, 8471852.

Steel, R. G. D. and Torrie, J. H. (1980) Principles and Procedures of Statistics. Second ed. McGraw Hill Book Company, New York.

Su G., Suh S.O., Schneider R.W. and Russin J.S. (2001) Host specialization in the charcoal rot fungus, Macrophominaphaseolina. Phytopathology 91, 120-126

Zveibil A., Mor N., Gnayem N. and Freeman S. (2012) Survival host-pathogen interaction and management of Macrophominaphaseolina on strawberry in Israel. Plant Dis. 96, 265e 272.

(Received 27/11/2018; accepted 10/1/2019) 